\title{
Flora da Reserva Ducke, Amazonas, Brasil: Gentianaceae
}

Hiltje Maas ${ }^{1} \&$ Paul J. M. Maas ${ }^{1}$

Gentianaceae Juss., Gen. Pl. 141. 1789.

Maas, P. J. M. 1985. Nomenclatural notes on Neotropical Lisyantheae (Gentianaceae). Proc. Kon. Ned. Akad. Wetensch. C. 88(4): 405-412.

Maas, P. J. M. \& P. Ruyters. 1986. Voyria and Voyriella (Saprophytic Gentianaceae). Fl. Neotrop. Monograph 41: 1-93.

Maguire, B. \& R. E. Weaver. 1975. The neotropical genus Tachia. J. Arnold Arb. 56:103-125.

Medium-sized to small herbs (sometimes saprophytic). Leaves opposite, scale-like in saprophytes. Inflorescence cymose, sometimes flowers terminal and solitary, or axillary. Flowers actinomorphic, 5-merous. Sepals 5, free or connate, sometimes with nectaries on the outer side (Irlbachia). Corolla 5-lobed, mostly with a long tube, lobes contorted. Stamens 5. Ovary superior, 1-2-locular, placentation mostly parietal, ovules many. Fruit a many-seeded capsule.
A family with $c .35$ genera and c. 500 species in the Neotropics. Throughout the Neotropics, but the highest number of species is found at high elevations in the Andes with genera like Gentianella (150 species) and Halenia (80 species). Represented in the Reserva Ducke by 4 genera and 8 species.

A quite variable family varying from tiny saprophytes to large herbs, to be distinguished by opposite leaves and a tubular corolla with contorted lobes. It may be confused with Apocynaceae, but in that family there is mostly latex present.

\section{Key to the genera of Gentianaceae of Reserva Ducke}

1. Tall, green herbs or shrubs.

2. Flowers solitary and subsessile in the leaf axils; flowers yellow, $6.5-9.5 \mathrm{~cm}$ long; leaf venation inconspicuous

2. Flowers in a bifurcate, many-flowered inflorescence; flowers greenish, 2-3 cm long; leaf venation conspicuous

1. Irlbachia

1. Very small, saprophytic herbs.

3. Flowers solitary, sometimes in a few-flowered inflorescence; calyx lobes connate; corolla far exceeding the calyx 3. Voyria

3. Flowers in a many-flowered, more or less globose inflorescence; calyx lobes free; corolla hardly exceeding the calyx 4. Voyriella

\section{Irlbachia}

Irlbachia Mart., Nov. Gen. Sp. Pl. 2 (2): 101. 1826 (1827).

A genus with $c .20$ species, most of which occur in tropical South America. In the Reserva Ducke the genus Irlbachia is represented by 1 subspecies only.
1.1 Irlbachia alata (Aubl.) Maas subsp. alata Proc. Kon. Ned. Akad. Wetensch. C. 88(4): 409. 1985.

Lisyanthus alatus Aubl., Hist. P1. Guiane 1: 204.t. 80. 1775.

Chelonanthus alatus (Aubl.) Pulle, Enum. Pl. Vasc. Surinam 376. 1906.

Slender herbs, 1-2 m tall, stems 4-angled to 4-winged at the base. Petioles absent.

Artigo recebido em 09/2004. Aceito para publicação em 04/2005.

${ }^{1}$ Project Herbarium, Institute of Systematic Botany, Heidelberglaan 2, 3584 CS Utrecht, The Netherlands. 
Leaves ovate to elliptic, 6-15 cm long, 2.5$8 \mathrm{~cm}$ wide, base decurrent, apex acute, pinnately veined with 1-3 pairs of secondary veins. Inflorescence an up to 25 -flowered compound, bracteate, bifurcate cyme. Pedicels 5-15 mm long. Flowers greenish. Calyx 6-10 mm long, lobes with distinct central, glandular, thickened zone. Corolla funnelform to salverform, $20-30 \mathrm{~mm}$ long. Ovary 2-locular. Style $20 \mathrm{~mm}$ long. Capsule ellipsoid, almost woody, 10-20 mm long, crowned by the persistent style base. Seeds cubical, less than $0.5 \mathrm{~mm}$ in diam.

From South Mexico to Bolivia and Brazil.

In non-inundated forest, on sandy to clayey soil.

Flowering and fruiting in June and February.

8.XI.1994 (fl) Assunção, P. A. C. L. 69 (INPA K MG MO NY SP U); 3.II.1995 (fl, fr) Costa, M. A. S. \& Nascimento, J. R. 127 (BM G IAN INPA K R RB U US); 14.XII.1966 (fl) Prance, G. T. et al. 3635 (INPA U); 14.VI.1988 (fr) Santos, J. L. 925 (INPA K MGMO NYSPU); 18.I.1996(fl) Sothers, C. A. 758(INPA); 2811-1964 (fl, fr) Vogel 247a (U).

Irlbachia alata subsp. alata is a herb with greenish funnel- to salverform flowers, arranged in a bifurcate inflorescence, and basally 4-angled to 4-winged stems.

\section{Tachia}

Tachia Aubl., Hist. Pl. Guiane 1: 75, t. 29. 1775.

A genus with nine species occurring in tropical northern and western South America.

2.1 Tachia grandiflora Maguire \& Weaver, J. Arnold Arb. 56: 117. 1975.

Shrub, 1-3 m tall. Leaf petioles 5$10 \mathrm{~mm}$ long. Lamina narrowly elliptic, 10$22 \mathrm{~cm}$ long, $4-7 \mathrm{~cm}$ wide, midrib raised on upper side, keeled on lower side, base acute, apex abruptly acuminate (acumen 10-15 m long), with obscure, pinnate venation. Flowers axillary, solitary, yellow. Pedicels 1-3 mm long. Calyx 20-28 mm long, tube 10$20 \mathrm{~mm}$ long, lobes slightly winged, narrowly triangular, 6-12 mm long. Corolla salverform, 65-95 mm long, tube 50-70 mm long, 20$25 \mathrm{~mm}$ in diam. at the apex, lobes broadly ovate, 15-25 mm long, shortly apiculate. Ovary 2-locular. Capsule narrowly ellipsoid, 20-30 mm long. Seeds subglobose, spiny, less than $0.5 \mathrm{~mm}$ in diam.

Central Amazonian Brazil and French Guiana.

In non-inundated forest, on clayey soil.

Flowering and fruiting from January to June.

13.III.1996 (fl) Campos, M. T. V. do A. \& Silva, C. F. da 549 (INPA U); 13.V.1995 (fl) Cordeiro, I. et al. 1546 (INPAU); 6.I.1995 (fl) Costa, M. A. S. et al. 85 (INPA K MG NY U); 24.V.1996 (fl) Costa, M. A. S. \& Assunção, P. A. C. L. 544 (INPA K U); 17.V.1988 (fl) Coêlho, D. 46-D (INPAK U); 28.IV.1988 (fl) Ramos, J. F. 1888 (INPAU); 4.VI.1993 (fl) Ribeiro, J. E. L. S. et al. 839 (G IAN INPA K MO RB SPU US); 8.IV.1994 (fl) Ribeiro, J. E. L. S. et al. 1263 (INPA K U).

The genus Tachia is unique among lowland, neotropical Gentianaceae in being a shrub or treelet with solitary, axillary flowers. All species of this genus have a very peculiar feature only visible when dried: the specimens become glued to the newspapers in which they were dried, by the secretion of a sticky substance probably from the axils of the leaves. The way this secretion is formed and its functon is still completely unknown, and needs further investigation.

\section{Voyria}

Voyria Aubl., Hist. Pl. Guiane 1: 208-209, t. 83. 1775.

Saprophytic herbs. Stems mostly simple, terete. Leaves small and scale-like. Inflorescence a terminal few-flowered, bifurcate cyme, or the plant having a solitary flower only. Bracts and bracteoles present. Flowers variously coloured, (4-)5-merous. Calyx tubular to campanulate, small. Corolla salverform to funnelform, far exceeding the calyx. Stamens generally 5, filaments conspicuous or virtually absent, anthers introrse, often coherent just below the stigma. 
Ovary 1-locular, with 2 parietal placentas, sometimes provided with 2 glands. Fruit a capsule, often indehiscent, sometimes septicidally dehiscent. Seeds many, filiform or subglobose.
A genus with 19 species, 18 of which occur throughout the Neotropic and one in western tropical Africa. In the Reserva Ducke two genera are found, Voyria represented by four species, and Voyriella with one species.

\section{Key to the species of Voyria of Reserva Ducke}

1. Flowers yellow to whitish.

2. Corolla c. $40 \mathrm{~mm}$ long, yellow; seeds filiform; thecae unappendaged 1. V. aphylla

2. Corolla 7-23 mm long, yellow to whitish; seeds subglobose; thecae with tail-like, hairy appendages 6. V. spruceana

1. Flowers white to blue or pinkish.

3. Corolla funnelform, white to pinkish, $70-115 \mathrm{~mm}$ long 4.V. clavata

3. Corolla salverform, white to blue or pinkish, 10-50 mm long.

4. Flowers solitary, blue to white; buds nodding; roots in star-like clumps 7. V. tenella

4. Flowers in several-flowered inflorescences; buds erect; roots differently shaped.

5. Calyx irregularly lobed; flowers white to bluish or pinkish, 30-50 mm long 2. V. caerulea

5. Calyx regularly lobed; flowers white, $10-18 \mathrm{~mm}$ long.

6. Corolla lobes $c$. $13 \mathrm{~mm}$ long, apex caudate; calyx lobes 7-10 mm long

3. V. aff. chionea

6. Corolla lobes 2-5 mm long, apex acute; calyx lobes $2-3 \mathrm{~mm}$ long .. 5. V. corymbosa

3.1 Voyria aphylla (Jacq.) Pers., Synops. pl. 1: 284. 1805; Maas \& Ruyters, Fl. Neotrop. 41: 39. fig. 15. 1986.

Gentiana aphylla Jacq., Select. Stirp. Amer. Hist. 87. t. 60, fig. 3. 1763.

Saprophytic herbs, 10-20 cm high, stems and leaves yellowish. Leaves $c .5 \mathrm{~mm}$ long. Flowers solitary. Calyx yellowish, 4-5 mm long. Corolla yellow, salverform, c. $40 \mathrm{~mm}$ long, lobes ovate-triangular, $6 \mathrm{~mm}$ long, apex acute. Ovary eglandular. Capsule narrowly ellipsoid, $15 \mathrm{~mm}$ long, dehiscent. Seeds filiform.

Throughout the Neotropics.

In non-inundated forest, once recorded from campinarana forest, on sandy or clayey soil.

Flowering in January, March to May, and from August to October, fruiting in April. 18.I.1995 (bd) Costa, M.A. S. \& Nascimento, J. R. 105 (INPA); 9.IV.1995 (fl) Costa, M. A. S. etal. 204 (INPA); 4.V.1995 (fl, fr) Costa, M. A. S. et al.276 (U); 18.X.1995 (fl) Costa, M. A. S. \& Assunção, P. A. C.L. 394 (INPA U); $19 . I V .1996$ (fl) Costa, M. A. S. \& Assunção, P.A. C. L. 495 (INPA); $29 . \mathrm{IX} .1977$ (fl) Maas, P. J. M. et al.
3078 (U); 8.VIII.1973 (fl) Prance, G. T. et al. 18737 (INPA); $3 . I I I .1994$ (fl) Ribeiro, J. E. L. S. et al. 1214 (INPA); 6.III.1996 (fl) Sothers, C. A. 813 (INPA).

Voyria aphylla is characterized by solitary, yellow, relatively large flowers $(c$. $40 \mathrm{~mm}$ long).

3.2 Voyria caerulea Aubl., Hist. Pl. Guiane 1: 211.t. 83, fig. 2. 1775; Maas \& Ruyters, Fl. Neotrop. 41: 48. fig. 18, 19b. 1986.

Saprophytic herbs, $10-20 \mathrm{~cm}$ high, stems and leaves white. Leaves $2-8 \mathrm{~mm}$ long. Inflorescence a dense, 2-7-flowered cyme, flowers sometimes solitary. Calyx lilac, 10$15 \mathrm{~mm}$ long, tube often split for most of its length, lobes unequal. Corolla white, sometimes bluish or pinkish, very fragrant, salverform, 30-50 mm long, lobes ovate, 5$7 \mathrm{~mm}$ long, apex obtuse. Ovary eglandular. Capsule fusiform, c. $15 \mathrm{~mm}$ long. Seeds subglobose.

The Guianas, the Venezuelan states of Amazonas and Bolivia, and Brazil (Amazonas, Bahia, Mato Grosso, Para). 
In non-inundated forest, on clayey soil.

Flowering from February to May, and in December, fruiting from March to May. 13.IV.1994(fl) Assunção, P.A. C. L. 16(INPA); 6.III.1996 (fl) Campos, M. T. V. do A. \& Pereira, E. da C. 539 (INPAU); 20.III.1996 (fl) Campos, M. T. V. do A. et al. 566 (INPA, U); $11 . I I .1996$ (fl) Costa, M. A. S. et al. 146 (INPA); 9.IV.1995 (fl) Costa, M. A. S. et al. 185 (INPA); 10.IV.1995 (fl) Costa, M. A. S. et al. 205 (INPA); 11.II.1994 (fl) Ribeiro, J. E. L. S. et al. 1206 (INPA); 5. XII.1969 (fl) Silva, M. F. da et al. 16 (INPA); 23.III.1995 (fl) Sothers, C. A. \& Pereira, E. da C. 360 (INPA); 6.III.1996 (fl) Sothers, C. A. 814 (INPA); 20.XII.1996 (fl) Souza, M. A. D. de \& Hopkins, M. J. G. 304 (INPA); $4 . I V .1994$ (fl) Vicentini, A. et al. 460 (INPA); 8.IV.1994 (fl) Vicentini, A. \& Silva, C. F. da 474 (INPA); 8.IV.1994 (fl) Vicentini, A. et al. 485 (INPA); 13.V.1994 (fl) Vicentini, A. et al. 547 (INPA).

Voyria caerulea is a mostly whiteflowered species with a very typical irregularly lobed and often longitudinally split calyx.

3.3 Voyria aff. chionea Benth., Hooker's J. Bot. Kew Gard. Mic. 6: 197. 1854.

$V$. aff. chionea differs from $V$. chionea by the very long (caudate) apex of both calyx and corolla lobes. These collections may well represent a yet undescribed species.

30.IV.1996 (fl) Costa, M. A. S. \& Assunção, P.A. C. L. 503 (INPA); V.1997 (fl) Souza, M.A.D. de \& Hopkins, M. J. G. 369 (INPA); 1.III.1996 (fl) Ribeiro, J. E. L.S. \& Silva, C. F. da 1805 (INPA U).

3.4 Voyria clavata Splitg., Tijdschr. Natuurl. Gesch. Physiol. 7: 133, t. 1. 1840.

Occurring in the PDBFF reserves and the Walter Egler Reserve and to be expected in Reserva Ducke.

3.5 Voyria corymbosa Splitg., Tijdschr. Natuurl. Gesch. Physiol. 7: 136, t. 2. 1840.

Occurring in the PDBFF reserves and to be expected in the Reserva Ducke.

3.6 Voyria spruceana Benth., Hooker's J. Bot. Kew Gard. Misc. 6: 197. 1854; Maas \& Ruyters, Fl. Neotrop. 41: 71. fig. 20g-o. 1986.

Saprophytic herbs, 5-15 cm high, stems often orange. Leaves 1-9 mm long. Flowers solitary. Calyx 4-9 mm long, lobes slightly winged. Corolla yellow to whitish, salverform, 7-25 mm long, lobes narrowly triangular, 5$11 \mathrm{~mm}$ long, acute. Thecae with long hairy tail at the base. Ovary with glandular marks. Capsule narrowly ellipsoid, 6-8 mm long. Seeds subglobose.

From Costa Rica to Amazonian Peru, Bolivia and the Brazilian states of Amazonas, Pará, and Matto Grosso in the South.

In non-inundated forest, on clayey soil.

Flowering in January, March, April, June to October, and in December, fruiting specimen only collected in April.

13.IV.1994 (fl) Assunção, P. A. C. L. 15 (INPA); 13.VII.1994 (fl) Assunção, P. A. C. L. 18 (INPA); 20.III.1996 ( bd) Campos et al. 566A (U); 5.I.1995

(fl) Costa, M. A. S. \& Stumpe, P. 77 (U); 18.X.1995

(fl) Costa, M. A. S. \& Assunção, P. A. C. L. 395 (U); 29 IX 1977 (fl) Maas et al. 3080 (U); 12.XII.1968 (fl) Prance, G. T. et al. 9041 (INPA); 10 IX 1987 (fl) Pruski, J. F. et al. 3199 (NY U); 4.VII.1993 (fl) Ribeiro, J. E. L. S. et al. 1011 (U); 27.IV.1994 (fl) Ribeiro, J. E. L. S. et al. 1290 (INPA); 26.VIII.1957 (fl) Rodrigues, W. 571 (INPA); 23.III.1995 (fl) Sothers, C. A. \& Pereira, E. da C. 358 (INPA); 23.I.1996 (fl) Sothers, C. A. 787 (INPA); 29.III.1996 (fl) Sothers, C. A. \& Pereira, E. da C. 845 (INPA); 17.IV.1997 (fl) Souza, M. A. D. de 350 (U); 24.III.1994 (fl) Vicentini, A. et al. 455 (INPA); 6.IV.1994 (fl) Vicentini, A. et al. 479 (INPA); 7.VI.1994 (fl) Vicentini, A. \& Assunção, P. A. C. L. 570 (INPA); 23.VIII.1994 (fl) Vicentini, A. 680 (INPA).

Voyria spruceana is a small yellow (or white) flowered saprophyte characterized by stamens with thecae provided with a hairy tail. The species is very variable in flower color (yellow to white) and in flower size.

3.7 Voyria tenella Hook., Bot. Misc. 1: 47. t. 25, fig. B. 1829; Maas \& Ruyters, Fl. Neotrop. 41: 73. fig. 31. 1986.

Herbs, to $10 \mathrm{~cm}$ high, stems and leaves white. Roots tuberous, forming a starlike clump. Leaves 2-3 mm long. Flowers solitary, slightly fragrant. Buds nodding. Calyx 2.5-4 mm long. Corolla white to blue, salverform, 9-22 mm long, lobes 5-6 mm long, obtuse. Ovary basally provided with 2 long- 
stalked glands. Capsule ellipsoid, 4-5 mm long, dehiscent. Seeds filiform.

Throughout the Neotropics.

In non-inundated forest, on clayey soil.

Flowering in April and June, fruiting in April. 10.IV.1995 (fl) Costa, M. A. S. et al. 206 (INPA U); 11.VI.1958 (fl) Ferreira, E. 58-287 (INPA); 4.IV.1994 (fl) Vicentini, A. et al. 461 (INPA).

Voyria tenella is a saprophyte which can be recognized by nodding buds, bluish flowers, and rootlets forming a star-like clump.

\section{Voyriella}

Voyriella (Miq.) Miq., Stirp. Surinam. Select. 146. 1851.

A monotypic genus occurring in tropical South America.

4.1 Voyriella parviflora (Miq.) Miq., Stirp. Surinam. Select. 146. 1851; Maas \& Ruyters, Fl. Neotrop. 41: 80. f. 19, 35. 1986.

Voyria parviflora Miq., Tijdschr. Wis.Natuurk. Wetensch. Eerste Kl. Kon. Ned. Inst. Wetensch. 2: 122. 1849.

Saprophytic herbs, $2-10 \mathrm{~cm}$ high, completely white. Leaves 3-4 mm long.
Inflorescence a dense, globose, bracteate, mostly many flowered, terminal or axillary cyme. Sepals free, 4-5 mm long. Corolla white, campanulate, 5-6 mm long (hardly exceeding the calyx), lobes ovate-triangular, 1-1.5 mm long, apex acute, recurved. Ovary eglandular. Capsule ovoid, 4-5 mm long, crowned by the persistent style. Seeds subglobose.

Panama, Colombia, Venezuela, the Guianas, and Amazonian Brazil.

In non-inundated forest, on clayey soil.

Flowering and fruiting from March to May.

20.III.1995 (fl, fr) Costa, M. A. S. et al. 170 (U); 9.IV.1995 (fl, fr) Costa, M. A. S. et al. 191 (INPA U); 4.V.1995 (fl fr) Costa, M. A. S. et al. 277 (INPA); 30.IV.1996 (fl) Costa, M. A. S. \& Assunção, P. A. C. L. 502 (INPA U); $1 . I I I .1996$ (fl) Ribeiro, J. E. L. S. \& Silva, C. F. da 1804 (INPA U); 20.IV.1961 (fl) Rodrigues, W. \& Coêlho, L. 2400 (INPA); 6.III.1996 (fl) Sothers, C. A. 812 (INPA); 10.V.1994 (fl, fr) Vicentini, A. et al. 530 (INPA U).

Voyriella parviflora can be recognized by its subglobose, many-flowered inflorescence, free calyx lobes, and a white corolla barely exceeding the calyx. 
